\title{
Distribusi Komponen Darah Thrombocyte Concentrate (TC)
}

\section{Distribution of Blood Components Thrombocyte Concentrate (TC)}

\author{
GINA ALMIRAH \\ NURPUJI MUMPUNI \\ FRANSISCA ROMANA SRI SUPADMI
}

\author{
Jurusan Teknologi Bank Darah Unjani Yogyakarta \\ Jl. Brawijaya, Ringroad Barat, Ambarketawang, Gamping, Sleman, Yogyakarta \\ Email:almirahgina28@gmail.com; siskatbd.ayani@gmail.com
}

\begin{abstract}
Abstrak
Transfusi darah menjadi komponen penting dalam pengelolaan pasien dengan luka pada kasus kecelakaan, kondisi bedah, keganasan, komplikasi kehamilan, anemia, hemodialisa, dan kondisi medis yang lainnya. Darah yang dipindahkan dapat berupa darah lengkap dan komponen darah seperti Packed Red Cells (PRC), Thrombocyte Concentrate (TC), Anti Hemofilia Factor (AHF)/ Cryoprecipitate, Fresh Frozen Plasma (FFP), Buffy Coat (BC), Liquid Plasma (LP). Penelitian ini bertujuan untuk mengetahui distribusi komponen darah Thrombocyte Concentrate (TC) di UTD PMI Kota Pontianak. Desain penelitian ini merupakan penelitian kuantitatif dengan desain deskriptif, pendekatan waktu yang digunakan adalah retrospektif dengan mengumpulkan dan mengolah seluruh data distribusi komponen darah Thrombocyte Concentrate (TC) di UTD PMI Kota Pontianak Tahun 2019. Pengolahan dan analisis data dalam penelitian ini menggunakan aplikasi Statistical Product and Service Solutions (SPSS). Hasil analisis data jumlah permintaan TC sebanyak 5.427 kantong dalam 12 bulan, dengan rata-rata (Mean) 452,25 dan sebaran data (Std. Deviasi) 224,620 lebih besar daripada jumlah sediaan dan distribusi TC sebanyak 3.444 kantong dalam 12 bulan, dengan rata-rata (Mean) 287 dan sebaran data (Std. Deviasi) 79,681. Permintaan dan distribusi terbanyak adalah RSUD Dr. Soedarso, sedangkan yang paling sedikit adalah RSB Nabasa. Distribusi komponen darah TC di UTD PMI Kota Pontianak masih memerlukan peningkatan baik untuk persediaan maupun distribusi agar terpenuhi jumlah permintaan TC.
\end{abstract}

Kata Kunci : Distribusi Komponen Darah ; Thrombocyte Concentrate (TC)

\begin{abstract}
Blood transfusions become an important component in the management of patients with injuries to cases of accidents, surgical conditions, violence, pregnancy complications, anemia, hemodialysis, and other medical conditions. The blood transferred can be complete blood and blood components such as Packed Red Cells (PRC). Thrombocyte Concentrate (TC), Anti hemophilia Factor (AHF)/Cryoprecipitate, Fresh Frozen Plasma (FFP), Buffy Coat (BC), Liquid Plasma (LP). This research aims to determine the distribution of blood component Thrombocyte Concentrate (TC) in Indonesian Red Cross Blood Transfusion Service Pontianak City. The design of this research is a quantitative study with a descriptive design, the approach of time used is retrospective by collecting and processing all the distribution data of blood component Thrombocyte Concentrate (TC) in Indonesian Red Cross Blood Transfusion Service Pontianak City in 2019. Processing and analyzing data in this study using the Statistical Product and Service Solutions (SPSS) application. Data analysis results of the number of Thrombocyte Concentrate requests 5,427 bags in 12 months, with an average (Mean) of 452.25 and a data spread (Std. Deviation) of 224.620 is greater than the dosage amount and the distribution of Thrombocyte Concentrate 3,444 bags in 12
\end{abstract}


months, with an average (Mean) 287 and a data spread (Std. Deviation) 79.681. The most demand and distribution is Dr. Soedarso country general hospital, while the fewest are the Nabasa maternity hospital. The distribution of Thrombocyte Concentrate blood components in Indonesian Red Cross Blood Transfusion Service Pontianak City still needs improvement for both inventory and distribution to be fulfilled the number of Thrombocyte Concentrate requests.

Keywords: Distribution of Blood Components ; Thrombocyte Concentrate (TC)

\section{Pendahuluan}

Transfusi darah adalah proses pemindahan darah dari seseorang yang sehat ke orang sakit. Transfusi darah bertujuan untuk mengembalikan volume darah normal, mengganti kekurangan komponen darah, dan meningkatkan oksigenasi maupun hemostasis. Darah yang dipindahkan dapat berupa darah lengkap dan komponen darah seperti Packed Red Cells (PRC), Thrombocyte Concentrate (TC), Anti Hemofilia Factor (AHF)/ Cryoprecipitate, Fresh Frozen Plasma (FFP), Buffy Coat (BC), Liquid Plasma (LP). Transfusi darah menjadi komponen penting dalam pengelolaan pasien dengan luka pada kasus kecelakaan, kondisi bedah, keganasan, komplikasi kehamilan, anemia, hemodialisa, dan kondisi medis yang lainnya (Harsiwi \& Arini, 2018).

Trombosit merupakan fragmen sitoplasma megakariosit yang tidak berinti dan terbentuk di sumsum tulang. Dalam pematangannya, megakariosit terpecah menjadi 3.000-40.000 serpisahan sel, di mana serpihan-serpihan sel tersebut dinamai trombosit atau kepingan sel (Sadikin, 2013). Terdapat sekitar 250.000-400.000 trombosit dalam setiap $\mathrm{mm}^{3}$ darah manusia. Rata-rata masa hidup trombosit 5-10 hari (Hendrayati, 2015).

Berdasarkan data dari UTD PMI Kota Pontianak, pada tahun 2017 Jumlah permintaan TC sebanyak 622 kantong dengan jumlah produksi TC sebanyak 476 kantong yang didistribusikan ke Rumah Sakit seperti RS Soedarso sebanyak 182 kantong, RS Santo Antonius sebanyak 79 kantong, RS Yarsi sebanyak 26 kantong, RS Mitra Medika sebanyak 53 kantong, RS Promedika sebanyak 40 kantong, RS Kharitas sebanyak 16 kantong, RS Bhayangkara sebanyak 6 kantong, RS Sultan Syarif Mohamad Alkadrie sebanyak 23 kantong, RS Untan sebanyak 14 kantong, RS TK II Kartika Husada sebanyak 15 kantong, dan RS Anugerah Bunda Khatulistiwa sebanyak 21 kantong.

Berdasarkan uraian diatas peneliti tertarik untuk melakukan kajian tentang distribusi komponen darah Thrombocyte Concentrate (TC) di UTD PMI apakah sediaan darah Thrombocyte Concentrate (TC) terpenuhi untuk setiap bulan nya dan penyebaran permintaan TC merata sesuai dengan permintaan atau melebihi dari jumlah permintaan.

\section{Metode}

Penelitian ini menggunakan instrumen penelitian berupa lembar observasi. Lembar observasi digunakan sebagai pengamatan untuk mengukur gambaran distribusi. Untuk pengambilan data dalam penelitian ini dengan data sekunder yang sudah terdapat pada UTD PMI. Dalam pelaksanaan observasi, peneliti memilih dan mencatat hal-hal yang berkaitan dengan penelitian. Observasi yang dilakukan pada penelitian ini adalah permintaan, sediaan, dan distribusi TC ke BDRS. Setelah dilakukan observasi, data yang diperoleh akan dicatat di lembar observasi. Metode yang digunakan dalam penelitian adalah retrospektif dengan mengumpulkan dan mengolah seluruh data distribusi komponen darah Thrombocyte Concentrate (TC). 


\section{Hasil dan Pembahasan}

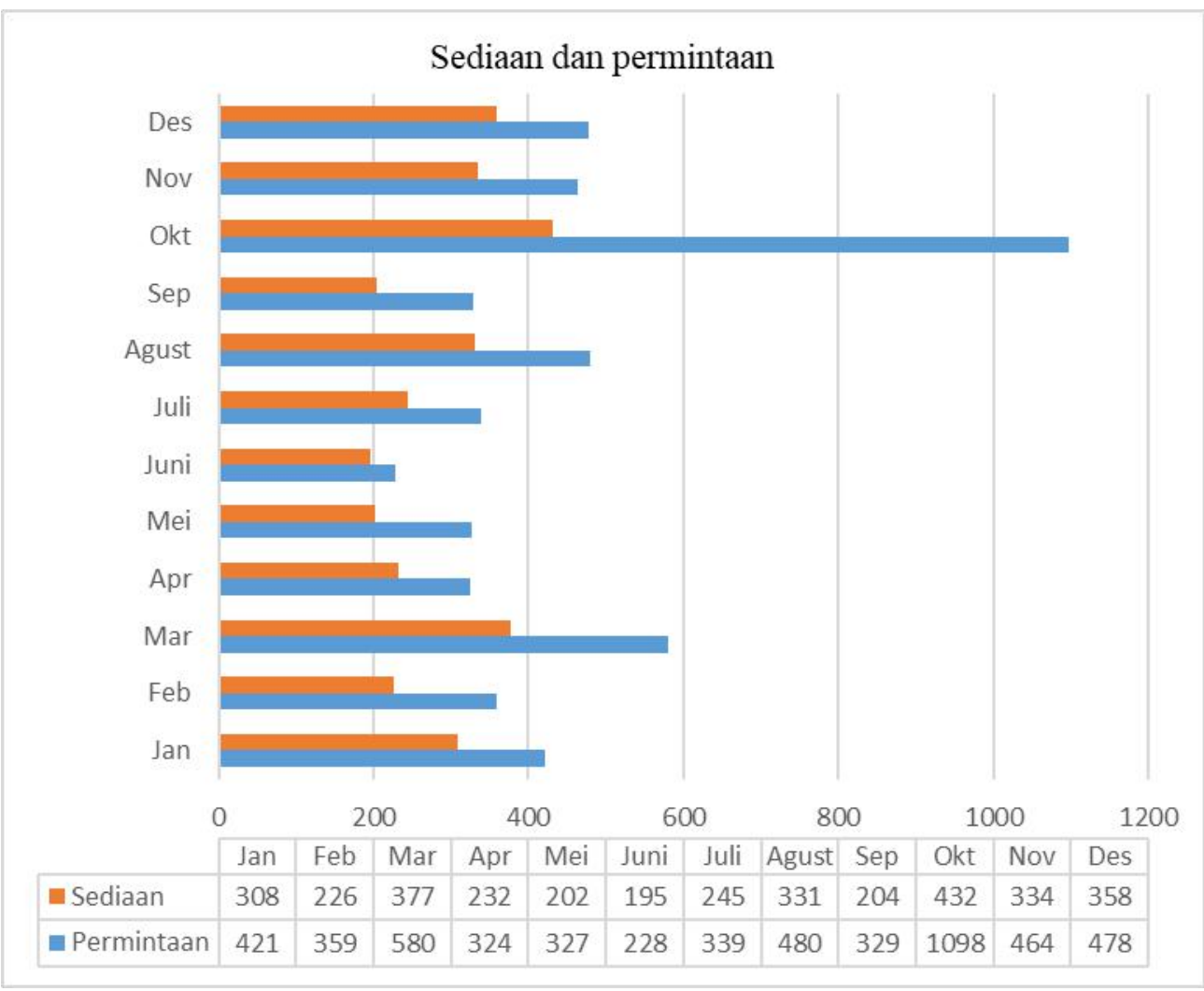

Gambar 1 Data sediaan dan permintaan TC

Berdasarkan data distribusi TC pada tahun 2017 bahwa jumlah permintaan TC sebanyak 622 kantong. Pada realisasinya jumlah persediaan TC sebanyak 476 kantong. Hal ini menyebabkan masih kurangnya persediaan TC di UTD PMI dikarenakan pada tahun 2017 permintaan jauh lebih banyak dibandingkan jumlah persedian. Hal itu pun terjadi pada tahun 2019 berdasarkan tabel 4.2 dan 4.4 pemenuhan kebutuhan atas permintaan TC jauh lebih tinggi dibandingkan jumlah persediaan $\mathrm{TC}$, dengan perbandingan jumlah permintaan sebanyak 5.427 kantong dan jumlah persediaan sebanyak 3.444 kantong.

Faktor yang menyebabkan kekurangan kebutuhan TC kemungkinan kurangnya kesadaran masyarakat untuk berdonor darah sukarela secara rutin dua bulan sekali, ini bisa terjadi karena beberapa faktor seperti mendengar isu-isu yang menyatakan bahwa mendonorkan darah dapat menghabiskan banyak darah, mengalami hal yang kurang menyenangkan ketika berdonor darah, dan sebagainya. Hal ini sesuai dengan penelitian Romana, F (2018) bahwa keyakinan seseorang dapat berasal dari pengalaman berdonor darah di masa lalu atau berasal dari informasi tidak langsung mengenai tindakan berdonor darah tersebut. Dapat dipengaruhi juga oleh faktor- faktor lain yang mengurangi atau menambah kesan kesulitan untuk melakukan tindakan berdonor darah secara reguler, misalnya lokasi UTD yang jauh dari tempat tinggal, sehingga akan membutuhkan sumber daya baik waktu, tenaga dan biaya untuk menuju ke lokasi. Trauma akibat kegagalan penusukan vena oleh petugas yang membuat sakit dan tidak nyaman juga dapat mempengaruhi keyakinan seseorang terhadap tindakan donor darah (Romana, 2018).

Solusi untuk memenuhi kebutuhan darah yaitu dengan cara melestarikan donor darah sukarela dan meningkatkan sosialisasi atau promosi di masyarakat seperti meningkatkan kegiatan mobile unit, promosi di masyarakat, dan kualitas komunikasi. Hal ini seperti 
penelitian Mirza (2020) mengatakan peningkatan rekrutmen donor dapat dilaksanakan melalui kampanye di berbagai media baik elektronik maupun cetak serta kerjasama dengan beberapa Lembaga Swadaya Masyarakat (LSM) yang peduli atas donor darah (Mirza, 2020).

Berdasarkan data penggunaan TC di UTD PMI Tahun 2019 banyaknya kebutuhan TC dikarenakan jenis penyakit yang membutuhkan penggunaan komponen TC seperti Demam Berdarah Dengue (DBD), trombositopenia, leukemia, pre-operasi dan pasca operasi. Hasil penelitian ini menunjukkan permintaan dan produksi yang paling banyak pada bulan Oktober, dikarenakan pada bulan tersebut banyak membutuhkan TC untuk penyakit Demam Berdarah Dengue (DBD).

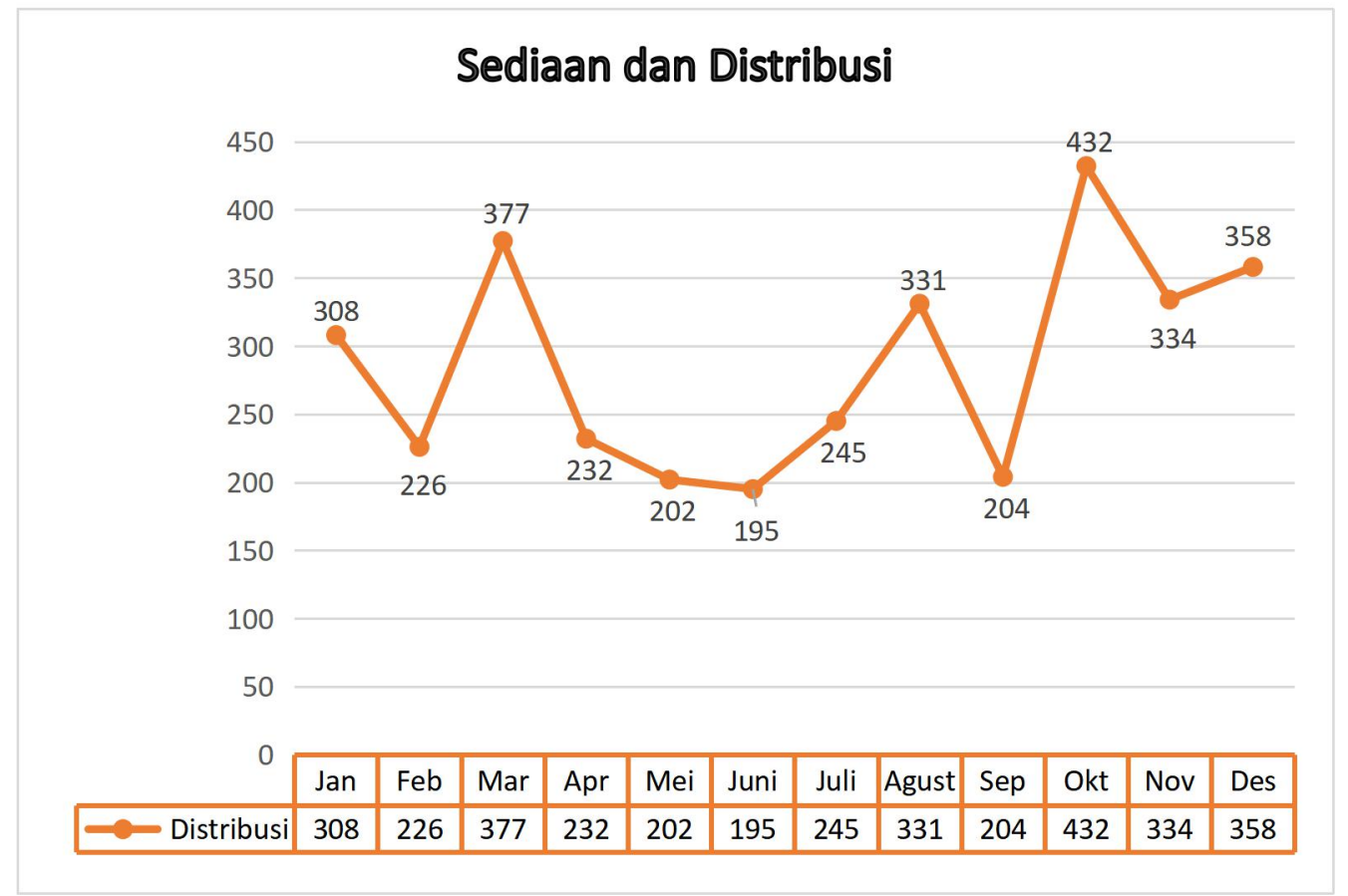

Gambar 2 Data sediaan dan distribusi TC

Berdasarkan gambar 2 hasil penelitian tersebut jumlah sediaan dan distribusi tahun 2019 memiliki data yang sama dikarenakan PMI menyediakan komponen TC sesuai dengan distribusi ke Bank Darah Rumah Sakit (BDRS), dan sediaan itu akan didistribusikan sesuai masing-masing BDRS yang melakukan permintaan TC. Jika dilihat pada gambar 4.1 dan 4.2 jumlah permintaan jauh lebih tinggi kemungkinan bahwa jumlah sediaan dan distribusi masih jauh dari pemenuhan permintaan BDRS yang membutuhkan komponen TC. Hal ini sesuai dengan Data Direktorat Pelayanan Kesehatan Primer (2018) yang menyatakan bahwa jumlah minimal kebutuhan darah ( $2 \%$ dari jumlah penduduk) di Kalimantan Barat adalah 97.235 kantong dengan jumlah produksi darah sebanyak 36.837 kantong. Masih banyaknya kekurangan darah tersebut yang mengakibatkan tidak terpenuhi nya kebutuhan TC (Data Direktorat Pelayanan Kesehatan Primer, 2018).

Penyebab banyaknya permintaan dan distribusi TC yaitu untuk pasien dengan penyakit leukemia, trombositopenia, DBD, pre-operasi, dan pasca operasi. Hal ini sesuai dengan penelitian Triyono, et al. (2017) mengatakan bahwa Transfusi Thrombocyte Concentrate (TC) adalah salah satu penggunaan komponen darah sebagai tindakan suportif pada pasien dengan trombositopenia atau kekurangan trombosit. Tindakan ini dapat bertujuan dalam menaikkan jumlah trombosit dengan kualitas yang baik di dalam tubuh (Triyono et al., 2017). 


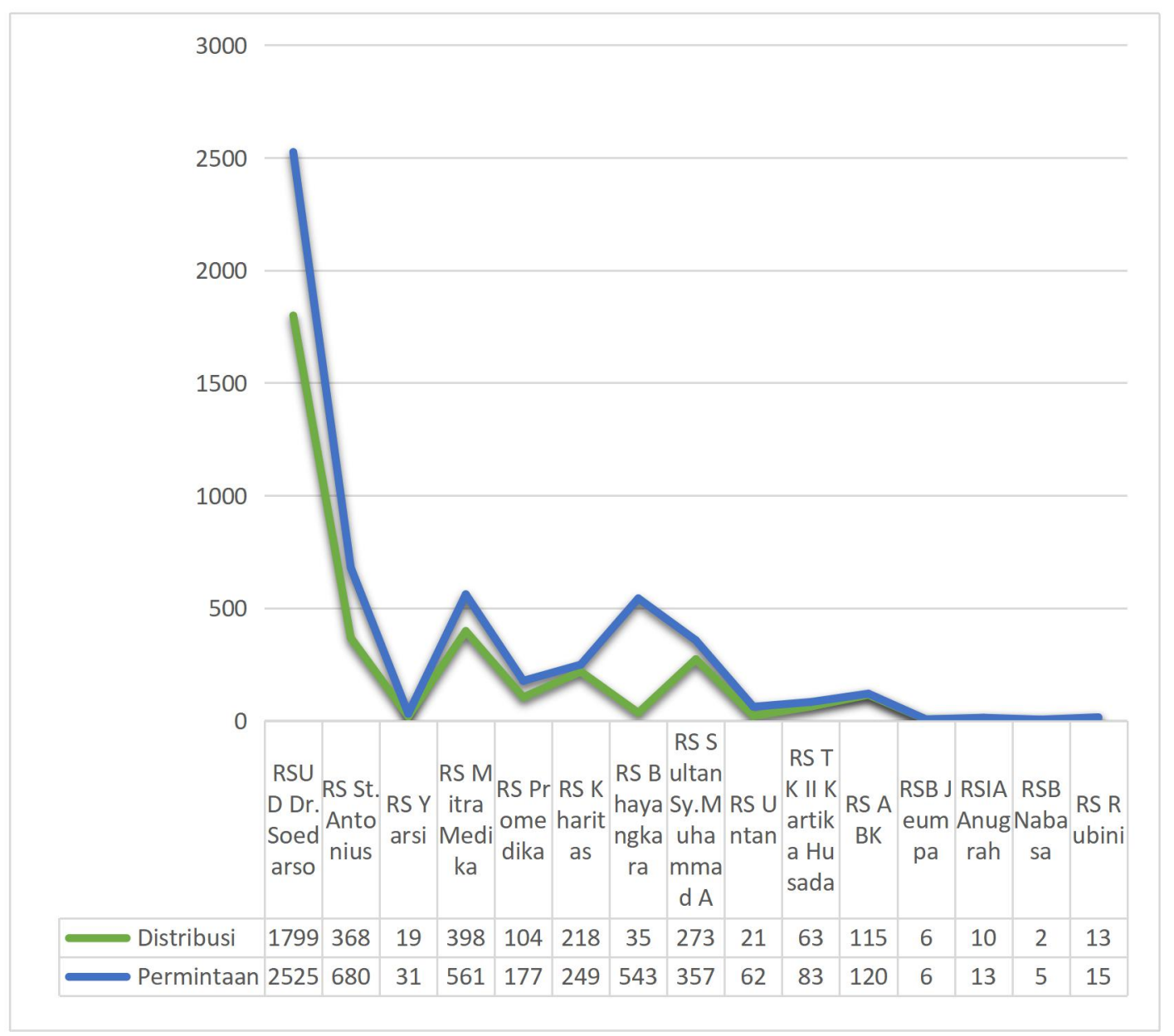

Gambar 3 Gambaran Distribusi TC ke BDRS di Rumah Sakit di Kalimantan Barat

Rumah Sakit Umum Daerah Dr. Soedarso adalah rumah sakit milik Pemerintah di Pontianak dengan rujukan tertinggi tingkat provinsi. Hal ini sesuai dengan penelitian Yurida, Sukamto and Muhardi (2018) bahwa Berdasarkan Peraturan Gubernur Kalimantan Barat Nomor 71 Tahun 2008 tentang Tugas Pokok, Fungsi dan Tata Kerja Rumah Sakit Umum Daerah Dokter Soedarso, maka Rumah sakit ini merupakan rumah sakit rujukan tertinggi tingkat provinsi dan sebagai Lembaga Teknis Daerah (LTD) tipe Kelas B Pendidikan. Berdasarkan Keputusan Menteri Kesehatan Republik Indonesia nomor HK.03.05/III/3970/09 tentang penetapan Rumah Sakit Umum Daerah Dokter Soedarso Pontianak Kalimantan Barat ditetapkan sebagai rumah sakit pendidikan, dalam hal ini bekerja sama dengan Fakultas Kedokteran Universitas Tanjungpura Pontianak. Ruang pelayanan yang terdapat di RSUD Dr. Soedarso merupakan ruang perawatan, ruang pengambilan obat jaminan kesehatan nasional (JKN) rawat jalan, ICU, ruang endoskopi, ruang instalasi diagnostic, ruang medical check-up, klinik fisioterapi, ruang operasi, apotek, dan lain sebagainya (Yurida et al., 2018).

Berdasarkan data penggunaan TC di UTD PMI Kota Pontianak, RSUD Dr. Soedarso merupakan RS dengan jumlah permintaan dan distribusi terbanyak di Pontianak pada tahun 2019. Adapun faktor yang membuat RSUD Dr. Soedarso menjadi RS yang terbanyak dalam permintaan dan distribusi antara lain: Rumah Sakit rujukan tertinggi di tingkat provinsi, melayani berbagai macam penyakit, dilengkapi berbagai fasilitas yang memadai, Rumah Sakit rujukan BPJS tingkat provinsi dan Nasional. Berdasarkan distribusi RSUD Dr. Soedarso memerlukan TC untuk pasien dengan riwayat Leukemia, trombositopenia, DBD, pre-operasi, dan pasca operasi. 
Penyakit dengan jumlah kebutuhan TC terbanyak adalah penyakit leukemia. Pemberian komponen darah TC dapat menjadi terapi dalam penyakit leukemia akut. Hal ini sesuai dengan penelitian Nency dan Sumantri (2016) mengatakan bahwa TC sudah digunakan untuk terapi suportif pada kondisi mielosupresif berat seperti pada leukemia akut maupun tumor padat. Meskipun indikasi transfusi TC bervariasi, namun penggunaannya untuk profilaksis pasca kemoterapi dosis tinggi akhirnya diperbolehkan setelah banyak data yang membuktikan bahwa tanpa adanya profilaksis TC pada acute myeloblastic leukemia (AML) $20 \%-30 \%$ akan terjadi perdarahan berat dan 34\%-58\% pada pasien pasca transplantasi alogenik. Dosis rendah TC sama efektifnya dalam mencegah perdarahan pada pembedahan dibandingkan dengan dosis yang lebih tinggi. Sampai saat ini belum ada penelitian random tentang batasan jumlah trombosit untuk tindakan invasif maupun operasi mayor (Nency \& Sumantri, 2016).

RS yang paling sedikit jumlahpermintaan dan distribusi TC adalah RSB Nabasa. Hal ini sesuai dengan data penggunaan komponen darah di UTD PMI Kota Pontianak tahun 2019 RS Bersalin Nabasa lebih banyak membutuhkan komponen darah PRC daripada komponen TC ataupun Whole Blood. Hal ini dikarenakan di rumah sakit tersebut lebih banyak pasien yang membutuhkan darah untuk ibu melahirkan yang kekurangan darah atau Anemia. Penggunaan TC yang ada di RS Bersalin Nabasa yang digunakan untuk keperluan trombositopenia pada ibu hamil.

Penyakit yang sering terjadi pada saat kehamilan ataupun melahirkan adalah penyakit trombositopenia. Trombositopenia beresiko lebih besar terhadap perdarahan. Hal ini sesuai dengan penelitian Saputra, B. A, et al (2018) mengatakan bahwa trombositopenia biasanya terjadi pada $8-10 \%$ dari semua persalinan, yang paling sering adalah trombositopenia gestasional, sebesar $75 \%$ kasus. Kebanyakan kasus kehamilan dengan trombositopenia merupakan trombositopenia ringan dan jinak, namun memiliki pengaruh terhadap timbulnya komplikasi yang berat pada ibu dan bayi. Tanda-tanda trombositopenia biasanya muncul jika nilai trombosit $<50.000 / \mu \mathrm{L}$, seperti petekie, epistaksis, hematuria, dan perdarahan gastrointestinal. Secara umum, trombositopenia pada kehamilan merupakan kelainan hematologik paling sering kedua setelah anemia defisiensi besi selama kehamilan. Penanganan kasus trombositopenia tergantung pada keadaan info klinis yang mendasari (Saputra et al., 2018).

\section{Simpulan dan Saran}

\section{Simpulan}

Berdasarkan hasil penelitian yang diperoleh, maka kesimpulan yang dapat diambil mengenai gambaran distribusi komponen darah Thrombocyte Concentrate (TC) di UTD PMI Kota Pontianak tahun 2019 adalah sebagai berikut:

1. Banyaknya jumlah permintaan komponen darah TC di UTD berjumlah 5.427 kantong dengan jumlah sediaan dan distribusi sejumlah 3.444 kantong menunjukkan bahwa di UTD masih memerlukan peningkatan baik untuk persediaan maupun distribusi agar terpenuhi jumlah permintaan TC.

2. Permintaan dan distribusi terbanyak pada bulan Oktober dengan jumlah permintaan sebanyak 1.098 kantong, distribusi sebanyak 432 kantong, dan yang paling sedikit pada bulan Juni dengan jumlah permintaan sebanyak 228 kantong, distribusi sebanyak 195 kantong.

3. Komponen darah Thrombocyte Concentrate (TC) di UTD sebagian besar didistribusikan ke RSUD yang memiliki jumlah paling banyak dalam permintaan dan distribusi TC dengan jumlah permintaan sebayak 2.525 kantong, distribusi sebanyak 1.799 kantong, dan RSB dengan jumlah permintaan dan distribusi yang paling sedikit dengan jumlah permintaan sebanyak 5 kantong, distribusi sebanyak 2 kantong. 


\section{Saran}

Perlu peningkatan persediaan darah khususnya komponen TC dengan cara mengajak dan memotivasi masyarakat rutin mendonorkan darahnya secara sukarela agar persediaan darah semakin meningkat setiap tahunnya.

\section{Daftar Pustaka}

Dinas Kesehatan Kota Pontianak. (2018). Dinas Kesehatan Kota Pontianak Profil Kesehatan Kota Pontianak Tahun 2018 Visi Pemerintah Kota Pontianak Visi Dinas Kesehatan Kota Pontianak.

Harsiwi, U. B., dan Arini, L. D. D. (2018). Tinjauan Kegiatan Donor Darah Terhadap Kesehatan Di Pmi Karanganyar, Jawa Tengah Tahun 2018. Jurnal Ilmiah Rekam Medis Dan Informatika Kesehatan, 8(1), 50-56. Availableat: https://www.ejurnalinfokes.apikescm.ac.id/index.php/infokes/article/download/196/16 dikases tanggal 29 Februari 2020 jam 12.30

Hendrayati, T. D. (2015). Pengaruh Daun Rebusan Pegagan (Centella Asiatica (L.) Urban) Terhadap Jumlah Keping Darah (Trombosit) Pada Mencit (Mus Musculus L.) dan Pemanfaatannya Kebagai Karya Ilmiah Populer. c:/Users/Admin/Documents/AKTI/referensi/TC- Titin Dwi Hendrayati- 110210103081 akses tanggal 29 Maret 2020 jam 19.30 .

Mirza, M. (2020). Strategi komunikasi PMI Kota Tangerang dalam memenuhi kebutuhan stok darah selama bulan ramadhan 2019. Available at: http://ejournal.unis.ac.id/index.php/DK/article/viewFile/359/273 diakses tanggal 16 Juli 2020 jam 16.40.

Nency, Y. M., dan Sumanti, D. (2016). Latar Belakang Penyakit pada Penggunaan Transfusi Komponen Darah pada Anak. Sari Pediatri, 13(3), 159. https://doi.org/10.14238/sp13.3.2011.159-64 diakses 18 Desember 2019 jam 21.45.

Pusat Data dan Informasi Kementerian Kesehatan Rakyat Indonesia. (2018). 2242-7659 diakses tanggal 28 Februari 2020

Romana, F. (2018). Faktor-Faktor Yang Mempengaruhi Niat Untuk Tranfusi Darah Palang Merah Indonesia 'Factors That Influenced Intention To Donate Blood Regularly In Indonesian Red Cross Blood Transfusion Service Gunungkidul Regency', 3(September), pp. $1-10$.

Available

at: https://www.poltekkes-bsi.ac.id/jurnal/index.php/bsm/article/view/40/13 diakses tanggal 16 Juli 2020 jam 14.00.

Saputra, B. A., Rodiani, dan Puspita, R. D. (2018). Kehamilan dengan Trombositopenia. Medula, $8(1)$ 94-101. http://juke.kedokteran.unila.ac.id/index.php/medula/article/download/2132/pdfdiakses 28 Februari 16.52.

Triyono, T., Mulyono, B., Sutaryo, ., \& Sofro, A. S. (2017). Comparing P-Selectin (CD62P) expression in patients receiving non-leukodepleted vs leukodepleted thrombocyte concentrates. Journal of Thee Medical Sciences (Berkala Ilmu Kedokteran), 49(03), 121-127. https://doi.org/10.19106/jmedsci004903201704 diakses 2 Maret 2020 jam 20.30 .

Yurida, N. H., Sukamto, A. S. and Muhardi, H. (2018). Aplikasi Virtual Tour Pada Ruang Pelayanan RSUD Dr. Soedarso Pontianak, Jurnal Sistem dan Teknologi Informasi (JUSTIN), 6(2), p. 92. doi: 10.26418/justin.v6i2.24821 diakses tanggal 14 Juli 2020 jam 23.45 . 